\title{
UPAYA PENERAPAN METODE LEAN THINKING PADA PROSES PELAYANAN FARMASI RAWAT JALAN
}

\author{
Komang Adhi Restudana ${ }^{1}$, Gede Sri Darma ${ }^{2}$ \\ Universitas Pendidikan Nasional, Bali - Indonesia ${ }^{1,2}$ \\ Email : komangadhi87@gmail.com,sridarma@undiknas.ac.id
}

\begin{abstract}
Pharmacy services in a hospital are an inaccessible part of the hospital services as a whole. The accumulation of prescriptions in the pharmacy will cause the prescription process to be long and long, which has an impact on customer waiting times, which of course will have a major impact on customer satisfaction. From the standard time set as Quality Indicators at Bali Jimbaran Hospital, namely: drug processing at the outpatient pharmacy of Bali Jimbaran Hospital is 60 minutes of concocted drugs, 30 minutes of non-concocted drugs. The purpose of this research is to identify activities starting from the input, process and results generated through the Lean approach. The method used is an observational action process research, using lean methods to photograph the outpatient pharmacy service process flow through document review, direct interviews, interviews. The result of the research is an improvement in waiting time, it can be seen that the NVA activities can be eliminated by $66 \%$ and VA activities show an increase of $44 \%$. With the many activities that are VA and the elimination of NVA activities, it will accelerate the process of outpatient pharmacy services at the Bali Jimbaran Hospital and improve customer satisfaction, which can be seen from the decrease in customer complaints against outpatient pharmacy services by up to $50 \%$, which was previously $80 \%$.
\end{abstract}

Keywords: Lean, Pharmacist, Waiting time, Value Added, Non-Value Added

\section{Pendahuluan}

Sistem kesehatan dewasa ini menjadi hal yang diprioritaskan oleh suatu negara karena derajad kedaulatan sebuah bangsa salah satunya dilihat dari kondisi kesehatan rakyatnya dan di dunia saat ini berfokus pada upaya menurunkan biaya dan disisi lain juga meningkatkan kualitas, meminimalisir waktu tunggu, memperbaiki patient safety serta berusaha untuk mengikuti perkembangan metode dan teknologi terbaru berkelanjutan dan konsisten (Kovacevic et al., 2016). Di Indonesia, berdasarkan UU Nomor 36 tahun 2009 tentang kesehatan, kesehatan 
adalah keadaan sehat, baik secara fisik, mental, spiritual maupun sosial yang memungkinkan setiap orang untuk hidup produktif secara sosial dan ekonomis. Pembangunan kesehatan bertujuan untuk meningkatkan kesadaran, kemauan dan kemampuan hidup sehat bagi setiap orang agar terwujud derajat kesehatan masyarakat yang setinggi-tingginya, sebagai investasi bagi pembangunan sumber daya manusia yang produktif secara sosial dan ekonomis. Sesuai dengan visi dari Presiden RI (Bapak Jokowi Dodo) yaitu Nawacitta dalam mewujudkan tata kelola Negara dan pemerintahan yang transparan, efektif, dan terpercaya salah satunya dengan penerapan e-governance. Dalam proses penerapannya di era disrupsi, inovasi di bidang kesehatan dengan aplikasi $e$-health dapat diukur melalui beberapa aspek penting salah satunya adalah value added (Muharam, 2019).

Pelayanan farmasi di rumah sakit merupakan bagian yang tidak dapat dipisahkan dari pelayanan rumah sakit secara keseluruhannya. Pelayanan farmasi di rumah sakit meliputi penerimaan resep sampai penyerahan resep kepada pasien. Alur pelayanan pasien rawat jalan poliklinik, dimulai dari pendaftaran sampai pelayanan obat. Pelayanan farmasi merupakan muara akhir, dimana sering terjadi penumpukan pasien yang menunggu obat, terutama pada jam-jam praktek dokter spesialis yang ramai (Febrianta et al., 2017). Penumpukan resep di farmasi, akan menyebabkan proses resep tersebut menjadi panjang dan lama, yang berdampak pada waktu tunggu pelanggan yang semakin lama, yang tentunya akan berdampak besar kepada kepuasan pelanggan. Persepsi pelanggan terhadap waktu tunggu resep ini, dapat memengaruhi citra pelayanan rumah sakit secara keseluruhan (Suryana, 2018). Faktor kunci yang perlu diperhatikan dalam pelayanan farmasi adalah: pelayanan yang cepat, ramah, disertai jaminan tersedianya obat dengan kualitas baik, harga yang kompetitif, adanya kerjasama dengan unsur lain di rumah sakit seperti dokter dan perawat, faktor lain seperti lokasi, kenyamanan dan keragaman komoditi (Aditama, 2002).

Lamanya waktu tunggu farmasi rawat jalan, sejalan dengan penelitian yang dilakukan oleh (Anggarani, 2002) didapatkan persepsi pelanggan terhadap waktu tunggu yang ditanggung saat menebus obatnya di Farmasi Rawat Jalan RS Haji Jakarta masih rendah. Dimana 106 responden menyatakan pelayanan resep Farmasi 
RS Haji Jakarta 'lama' sedangkan hanya 89 pelanggan menyatakan 'cepat' atau $45,7 \%$ dan $38,7 \%$. Hal ini juga diperkuat dari hasil wawancara mendalam yang menyarankan agar waktu pelayanan lebih efisien dan lebih cepat.

RSU Bali Jimbaran, sebagai salah satu rumah sakit swasta kelas C yang ada di kabupaten Badung yang berdiri pada tahun 2015, menunjukkan perkembangan yang cukup pesat. BOR rumah sakit saat ini (2019) sudah mencapai $85 \%$, dengan kunjungan rawat jalan rata-rata 5000 kunjungan setiap bulannya. Dengan adanya peningkatan jumlah kunjungan di RSU Bali Jimbaran, berdampak terhadap lamanya pelayanan rawat jalan, terutama pelayanan farmasi rawat jalan. Dengan meningkatnya kesadaran pasien dan masyarakat tentang pelayanan yang bermutu, sudah semestinya semua unit layanan melakukan pembenahan untuk meningkatkan mutu layanannya. Dari pengamatan awal yang dilakukan peneliti, terdapat penumpukan antrian di poliklinik rawat jalan, terutama saat pengambilan obat di farmasi.

Ada beberapa metode perbaikan yang banyak dipakai oleh organisasi di dunia, yaitu Theory of Constraints (TOC), Lean dan Six Sigma. Pada intinya, semua teori tersebut bertujuan melakukan perbaikan proses di dalam organisasi (Nave, 2002). Lean thinking melakukan penggunaan sumber daya yang seefisien mungkin, sumber daya dalam bidang pelayanan kesehatan sangat berharga dan perlu dioptimalkan agar dapat memberikan pelayanan paling maksimal (Malik \& Naeem, 2016). Dari literatur yang penulis baca, tentang Lean Hospital (Graban, 2012). Lean merupakan alat (tool set) yang memungkinkan Rumah Sakit melakukan pengelolaan ke arah yang baik untuk memperbaiki mutu layanannya dengan mengurangi kesalahan dan waktu tunggu, menghilangkan semua hambatan dan mendukung kegiatan dokter dan karyawan yang bertujuan meningkatkan kualitas pelayanan dan perawatan pasien. Di negara-negara barat, pendekatan pengelolaan pelayanan kesehatan sudah banyak dilakukan dengan metode Lean, Dickson et al, $\mathrm{Ng}$ et al dan Pester et al, semua menunjukkan keberhasilan dalam penerapan teknik Lean Manufacturing di IGD.

Penelitian dari Abuhejleh (2002) penerapan lean di rumah sakit menunjukkan hasil yang sangat baik, yaitu didapatkan ketepatan waktu pelayanan meningkat 
tajam dari 58\% menjadi 98\% dan waktu tunggu di farmasi rata-rata menurun 4 sampai 6 menit. Penerapan Lean sudah mulai masuk ke dalam sistem operasional suatu perusahaan, dan bukan hanya sebagai pengalaman saja, tetapi sudah menjadi bagian dari pengembangan bisnis.

Di Indonesia, ada beberapa Rumah Sakit yang sudah menerapkan Lean, diantaranya adalah RSUD Dr.H.M. Rabain Kabupaten Muara Enim, diperoleh cycle time diperpendek 16,4\% dan eliminasi waste sebear $98 \%$ (Novantri, 2016). Rumah Sakit RK Charitas Palembang menunjukkan adanya perbaikan berupa eliminasi waste di IGD dari 38 kegiatan menjadi 29 kegiatan dan value added activity meningkat sebesar 17,97\%. Di Rumah Sakit Hermina Depok, ditemukan Non-value added (waste) pasien sebesar $90 \%$, sedangkan kegiatan value added nya hanya $10 \%$ (Noviani, 2017).

Dari data pengerjaan resep, lama waktu tunggu untuk obat racikan dan non racikan melebihi waktu yang ditetapkan pada indikator mutu rumah sakit, yaitu untuk pengerjaan obat racikan melebihi 60 menit dan obat non racikan melebihi 30 menit. Dan juga data komplin pasien tahun 2019 masih tinggi tentang pelayanan obat di farmasi rawat jalan, sebesar $18 \%$.

\section{Tinjauan Pustaka}

\subsection{Lean}

Secara harfiah, kata "Lean" diartikan sebagai kurus (ramping), Lean didefinisikan sebagai seperangkat peralatan (tools set), sistem manajemen dan metedologi yang dapat mengubah rumah sakit dalam mengatur dan mengelola sehingga mengurangi kesalahan, mengurangi waktu tunggu, menghilangkan semua hambatan dan mendukung kegiatan dokter dan karyawan yang bertujuan meningkatkan kualitas pelayanan dan perawatan pasien (Graban, 2012). Menurut Gaspersz \& Fontana, (2011), definisi Lean adalah suatu pendekatan sistemik dan sistematik untuk mengidentifikasikan dan menghilangkan pemborosan (waste) atau aktivitas-aktivitas yang tidak bernilai tambah (Non-value adding activities) melalui peningkatan terus menerus secara radikal (radical continous improvement) dengan cara mengalirkan produk (material,work-in-proses,output) dan informasi 
menggunakan sistem tarik (pull system) dari pelanggan internal dan eksternal untuk mengejar keunggulan dan kesempurnaan.

Pada buku "Lean Thinking: Banish Waste and Create Wealth in Your Corporation" yang diterbitkan oleh Womack et al. (1992), dimana kedua penulis memandang konsep lean dari perspektif umum pada semua bidang dan level fungsi suatu perusahaan. Mereka menyatakan bahwa:

“...way to specify value, line up value creating actions in the best sequence, conduct these activities without interruption whenever someone requests them, and perform them more and more effectively.."

Lean dapat didefiniskan sebagai suatu upaya yang berkelanjutan dan terusmenerus untuk menghilangkan waste (pemborosan) dan meningkatkan value added (nilai tambah) produk barang maupun jasa agar memberikan customer value (Gaspersz \& Fontana, 2011). Berdasarkan definisi tersebut, maka tujuan dari Lean pada peningkatan terus menerus costumer value melalui identifikasi value added dan eliminasi kegiatan non-value added yang tidak memberikan nilai tambah yang merupakan pemborosan (waste). Akhir-akhir ini, konsep lean sudah banyak diterapkan di perusahaan-perusahaan di seluruh dunia. Dalam seluruh perusahaan atau lean enterprise memiliki 3 tujuan, diantaranya pada level customer, mencapai highest satisfication of needs, pada level prosess, mencapai total elimination of waste, pada level employee, mencapai respect for human dignity.

Hal yang sederhana dan bisa diterapkan mengenai lean yang berasal dari filosofi Toyota ada dua bagian Graban (2012) yaitu pertama, continous Improvement (perbaikan secara terus menerus). Perbaikan terus menerus dilakukan untuk memperbaiki sistem yang ada dengan meminimalisasi waste (Total elimination of waste). Pemborosan, muda, atau waste merupakan segala aktifitas yang tidak memberikan nilai pada pasien, yang harus dihilangkan, sehingga dapat menekan biaya. Contoh pemborosan di rumah sakit adalah waktu tunggu pasien untuk diperiksa dokter, waktu tunggu pasien untuk tahap berikutnya, adanya kesalahan yang membahayakan pasien, pergerakan yang tidak perlu, contohnya letak apotek dan kasir yang jauh. Kedua respect for people. Respect yang dimaksud dalam lean adalah memotivasi pegawai agar melaksanakan pekerjaan menjadi lebih 
baik dan kontruktif. Respect of people bermakna luas, bagaimana pimpinan berkomitmen dan mempercayai pegawainya untuk ikut serta dalam membantu menyelesaikan masalah dan mengurangi pemborosan, memotivasi pegawai agar lebih peduli terhadap pasien dan lingkungan rumah sakit tanpa mereka merasa jenuh dan terpaksa, membangun kerjasama antara pegawai pelaksana dan manajemen, sehingga tidak ada anggapan manajemen mengatur system, menyelesaikan masalah, membuat keputusan, sedangkan pegawai pelaksana hanya melaksanakan instruksi saja

\subsection{Penentuan nilai (value)}

Womack \& Jones menyatakan value hanya dapat didefinisikan oleh pelanggan akhir. Ini menjadi alasan mengapa kita harus mengetahui siapa customer kita dan setiap masing-masing pelanggan memiliki definisi berbeda mengenai value. Value merupakan kegiatan yang memberikan nilai tambah yang merupakan pengharapan dari pelanggan. Di rumah sakit, pelanggan dapat berupa pasien, keluarga pasien, dokter, pegawai rumah sakit, dan pihak asuransi. Namun pelanggan yang paling nyata adalah pasien. Aturan yang dipenuhi oleh suatu kegiatan untuk memberikan nilai tambah karena metode lean memberikan aturan spesifik apakah suatu kegiatan menambah value atau merupakan waste Graban (2012). Aturan yang harus dipenuhi tersebut adalah Konsumen/pelanggan bersedia membayar jasa pelayanan yang diberikan; Kegiatan harus mengubah produk atau jasa menjadi hal yang berarti bagi pelanggan dengan beberapa cara; Kegiatan harus dilakukan dengan tepat pada saat pertama dilakukan.

Suatu kegiatan dapat dikatakan value added atau non-value added dilihat dari berbagai perspektif, diantaranya produk, pasien, pegawai, atau pemberi pelayanan. Contoh kegiatan yang value added misalnya: dokter bedah melakukan operasi kepada pasien, dilakukan pemeriksaan spesimen pasien di laboratorium untuk mendukung diagnosa. Sedangkan kegiatan non-value added dalam dua kegiatan tersebut adalah dokter bedah menunggu untuk keterlambatan prosedur atau melakukan langkah langkah yang tidak perlu, spesimen pasien menunggu untuk dipindah sebagai satu batch. Apabila layanan yang diberikan tidak memenuhi ketiga kriteria di atas, maka tidak dapat dikategorikan sebagai value added activity bagi 
pasien. Beberapa kegiatan yang termasuk value added (VA) dan non-value added (NVA) seperti tabel di bawah ini.

Tabel 1. Contoh Value Added (VA) dan Non Value Added (NVA)

\begin{tabular}{|c|c|c|c|}
\hline Unit & Peran & Aktivitas VA & Aktivitas NVA \\
\hline Ruang Operasi & Ahli Bedah & $\begin{array}{l}\text { Tindakan Melakukan } \\
\text { Operasi }\end{array}$ & $\begin{array}{l}\text { Menunggu karena } \\
\text { keterlambatan operasi }\end{array}$ \\
\hline Farmasi & Apoteker & Membuat formulasi & $\begin{array}{l}\text { Melakukan proses ulang } \\
\text { obat yang dikembalikan } \\
\text { dari ruangan }\end{array}$ \\
\hline Rawat Inap & Perawat & $\begin{array}{l}\text { Memberikan obat } \\
\text { pada pasien }\end{array}$ & $\begin{array}{l}\text { Mencatat laporan } \\
\text { berkali-kali }\end{array}$ \\
\hline Radiologi & Radiografer & $\begin{array}{l}\text { Melakukan } \\
\text { pemeriksaan CT Scan } \\
\text { dengan terampil }\end{array}$ & $\begin{array}{l}\text { Melakukan pemeriksaan } \\
\text { yang tidak perlu. }\end{array}$ \\
\hline Laboratorium & Analis & $\begin{array}{l}\text { Interpretasi hasil } \\
\text { pemeriksaan }\end{array}$ & $\begin{array}{l}\text { Memperbaiki alat yang } \\
\text { rusak }\end{array}$ \\
\hline IGD & Pasien & $\begin{array}{l}\text { Diperiksa } \\
\text { diobati }\end{array}$ & Menunggu diperiksa \\
\hline
\end{tabular}

Sumber: Graban (2012)

\subsection{Waste}

Segala kegiatan dan proses yang terjadi di rumah sakit ditemukan banyak sekali pemborosan dan in-efisiensi, pegawai rumah sakit lebih banyak menghabiskan waktunya bukan untuk melakukan kegiatan pokok. Graban (2012) menyatakan perawat di unit rawat inap menghabiskan 25\%-50\% waktunya untuk kegiatan pelayanan yang langsung berhubungan dengan pasien, seperti mengecek status pasien, pemberian obat, menjawab pertanyaan, dan memberikan pedoman medis, berarti $50 \%-75 \%$ sisa waktuya banyak digunakan untuk melakukan kegiatankegiatan yang tidak bersifat value added atau merupakan pemborosan. Terdapat dua kategori pemborosan atau waste, yaitu type one waste dan type two waste. Type one 
waste. Merupakan aktivitas kerja yang tidak menciptakan nilai tambah dalam proses transformasi input menjadi output yang saat ini belum bisa dihilangkan karena berbagai alasan atau masih kita butuhkan. Tipe waste ini misalnya inspeksi, penyortiran, dan pengawasan. Menurut lean, contoh kegiatan kegiatan tersebut tidak mendatangkan value added, namun pada saat ini dibutuhkan untuk suatu tujuan yang bersifat korektif. Dalam jangka panjang waste tipe ini harus dapat dihilangkan atau dikurangi. Type two waste. Adalah aktifitas yang tidak memberikan nilai tambah dan harus segera dihilangkan. Kegiatan-kegiatan ini cenderung menghasilkan produk cacat atau defect, pengerjaan berulang atau re-work, atau dapat pula kegiatan tersebut sering terjadi kesalahan atau error yang dapat dihilangkan dengan segera. Tipe ini biasanya disebut waste saja, karena bentuknya berupa pemborosan yang sebenar-benarnya yang dapat diidentifikasikan dan dieliminasi secepatnya

\subsection{Value stream mapping}

\subsection{Diagram aliran proses (Spaghetti Chart)}

Diagram aliran berfungsi untuk memudahkan kita dalam melakukan perbaikan-perbaikan terutama terkait dengan tata letak dan arus aliran aktivitas. Biasanya berguna untuk mencegah kemacetan dan dipakai untuk menemukan susunan tata ruang baru yang paling efisien atau ekonomis jika ditinjau dari segi jarak dan waktu. Menghilangkan semua waste adalah tujuan dari konsep lean. Dalam merencanakan fasilitas seringkali luas ruang kurang dapat dimanfaatkan, dengan menggunakan konsep Lean waktu yang tidak efisien, seperti waktu tunggu, persediaan tidak efisien, kelebihan pasokan dan gerakan tidak efisien seperti berjalan berlebihan pada pasien ataupun pegawai. Untuk mengetahui alur proses yang terjadi dari setiap langkah proses dipetakan pada denah daerah tersebut. Diagram yang dihasilkan terkadang menyerupai spaghetti, jelas menggambarkan gerakan yang sia-sia dan daerah dimana bottle neck (kemacetan) terjadi, sering disebut diagram spaghetti. Penerapan lean dapat mengeliminasi pemborosan di Rumah Sakit. Beberapa alat (tools) lean yang dapat diterapkan di rumah sakit yaitu, yang pertama yakni Visual Management. Bentuk lain dari visual manajemen adalah standarisasi kerja, yaitu merupakan seperangkat alat yang dapat membantu 
memperlihatkan masalah, peringatan, peraturan dan lainnya dalam waktu yang cepat. Tujuannya adalah membuat waste, masalah dan kondisi abnormal menjadi terlihat oleh manajer maupun pegawai sehingga segera dicari solusinya. Gwendolyn Galsworth dalam Nindya menyatakan tujuan visual manajemen adalah untuk mengurangi defisit informasi di tempat kerja. Kelangkaan informasi akan menyebabkan orang banyak bertanya sehingga menimbulkan banyak pertanyaan berulang. Bentuk dari visual manajemen dapat berupa segala sesuatu yang terdokumentasi sehingga siapapun dapat mengakses informasi tanpa harus mendapat penjelasan dari suatu pihak, bentuk visual manajemen dapat berupa petunjuk arah, daftar dokter, daftar fasilitas, dan lain sebagainya. Kedua yakni 5 (Lima) S. 5 S merupakan konsep dasar yang dikembangkan pada manufaktur di Jepang terutama Toyota telah berhasil menjadi sebuah sistem kerja menjadi Lean. Metodologi 5 (Lima) S merupakan konsep untuk mengurangi pemborosan melalui peningkatan pengorganisasian tempat kerja dan visual manajemen. Metode ini membuat tempat kerja menjadi sangat teratur sehingga semua barang dapat ditemukan dan masalah dapat diselesaikan. John Touissant, CEO of Thedacare Health System (Winconsin) memperkirakan perbaikan dengan menggunakan metode 5 (Lima) $\mathrm{S}$ mengurangi jumlah pemborosan waktu rata-rata seorang perawat yang memiliki shift kerja 8 (delapan) jam dari 3,5 (Tiga setengah) jam sehari menjadi 1 (satu) jam perhari (Graban, 2012).

Ketiga adalah Kanban. Kanban merupakan metode yang dibangun berdasarkan konsep standarisasi kerja, 5 (Lima) $\mathrm{S}$ dan visual manajemen yang memberikan rumah sakit metode yang efektif dan sederhana untuk mengelola persediaan/inventory (Graban, 2012). Kanban merupakan istilah Jepang yang berarti tanda atau kartu biasanya dalam bentuk tanda fisik yang menunjukkan kapan waktunya untuk memesan barang, dari siapa dan jumlah yang diperlukan, namun saat ini dapat berupa tanda elektronik melalui sistem komputer. Keempat adalah Root Cause Analysis (RCA) dengan 5 Whys. Root Cause Analysis (RCA) adalah metode untuk mencari akar masalah dari ketidaksesuaian yang terjadi, untuk perbaikan dan mencegah permasalahan tersebut terulang kembali. 5 Whys mengacu pada sistem bertanya lima kali, mengapa ketidaksesuaian atau kegagalan terjadi 
dengan bertanya lima kali, sampai ditemukannya akar masalah dari kegagalan tersebut (Graban, 2012). Kelima adalah Kaizen (Continous Improvement). Kaizen merupakan suatu proses perbaikan secara terus menerus, dari proses-proses yang kecil, untuk dapat mengurangi pemborosan yang meliputi kegiatan PDCA (PlanDo-Check-Act). Ajarkan setiap orang untuk bekerja efektif dalam kelompokkelompok kecil agar bisa memecahkan masalah, kemudian mendokumentasikannya dan meningkatkan proses, mengumpulkan dan menganalisa data dan memanajemen diri sendiri. Kaizen merupakan konsep payung yang berorientasi kepada pelanggan, pengendalian mutu, robotic, gugus kendali mutu, otomatisasi, sistem saran, pemeliharaan dan produktivitas kerja, disiplin kerja, Kanban, tepat waktu, tanpa cacat, kooperasi karyawan dan manajemen dan pengembangan produk baru. Pemahaman dan penerapan kaizen terdiri dari beberapa komponen sebagai konsep utamanya, yaitu : (1) Kaizen dan manajemen, (2) Proses dan hasil, (3) PDCA/SDCA, (4) mengutamakan kualitas, (5) Berbicara dengan data, (6) Proses berikut adalah konsumen (Rother \& Shook, 2003).

\section{Metode Penelitian}

Penelitian ini akan mencoba menggali fenomena yang ada bagaimana dan mengapa fenomena kesehatan ini terjadi, kemudian dilakukan analisis dinamika korelasinya antara fenomena atau faktor resiko dengan faktor efek yang ditimbulkannya. Pertama-tama dilakukan observasi pendahuluan untuk penilaian lama waktu tunggu pada pelayanan farmasi rawat jalan di RSU Bali Jimbaran mulai dari penyerahan resep oleh pasien sampai penyerahan obat ke pasien. Selanjutnya untuk mengetahui mutu pelayanan di farmasi rawat jalan diperlukan pencarian data secara kualitatif sehingga memberikan variasi dan warna pada informasi yang dihasilkan (Wibowo, 2014). Metode yang digunakan adalah observasional action process research, dengan menggunakan metode lean untuk memotret alur proses pelayanan di farmasi rawat jalan melalui pengkajian dokumen, pengamatan langsung, wawancara dengan Direktur Utama, Kepala Unit, Apoteker, Apoteker pendamping, Tenaga Teknis Kefarmasian di RSU Bali Jimbaran. Penelitian kualitatif merupakan pendekatan jika ingin mengetahui hal-hal yang lebih mendalam dari sebuah fenomena, kejadian atau proses (Notoatmodjo, 2012). 


\subsection{Current State Value Stream Mapping Pelayanan Farmasi Rawat Jalan.}

Pada metode Lean, ada dua hal yang diutamakan yaitu value dan waste. Value yang dianalisa pada penelitian ini adalah alur proses farmasi rawat jalan, dimulai dari pasien keluar dari poliklinik untuk penyerahan resep ke farmasi sampai pasien mendapatkan obat yang dibutuhkan. Ada dua tipe waste, yaitu yang bersifat avoidable ( muda 2) dan non avoidable ( muda 1). Dengan mengetahui kegiatankegiatan mana yang termasuk waste, maka dapat diambil langkah-langkah apa saja yang dapat digunakan untuk mengeliminasi waste. Tujuan dari lean adalah membuat sistem lebih efektif dan efisien dengan menghilangkan waste yang tidak menambah value bagi pasien. Pasien yang sudah selesai melakukan pemeriksaan di masing-masing poliklinik, keluar dari ruang. Disetiap alur proses yang ada, seringkali proses tersebut tertunda, oleh karena petugas melayani permintan obat dari petugas IGD yang langsung bisa masuk ke ruang farmasi. Rata-rata 15 kali dalam satu shift jaga.

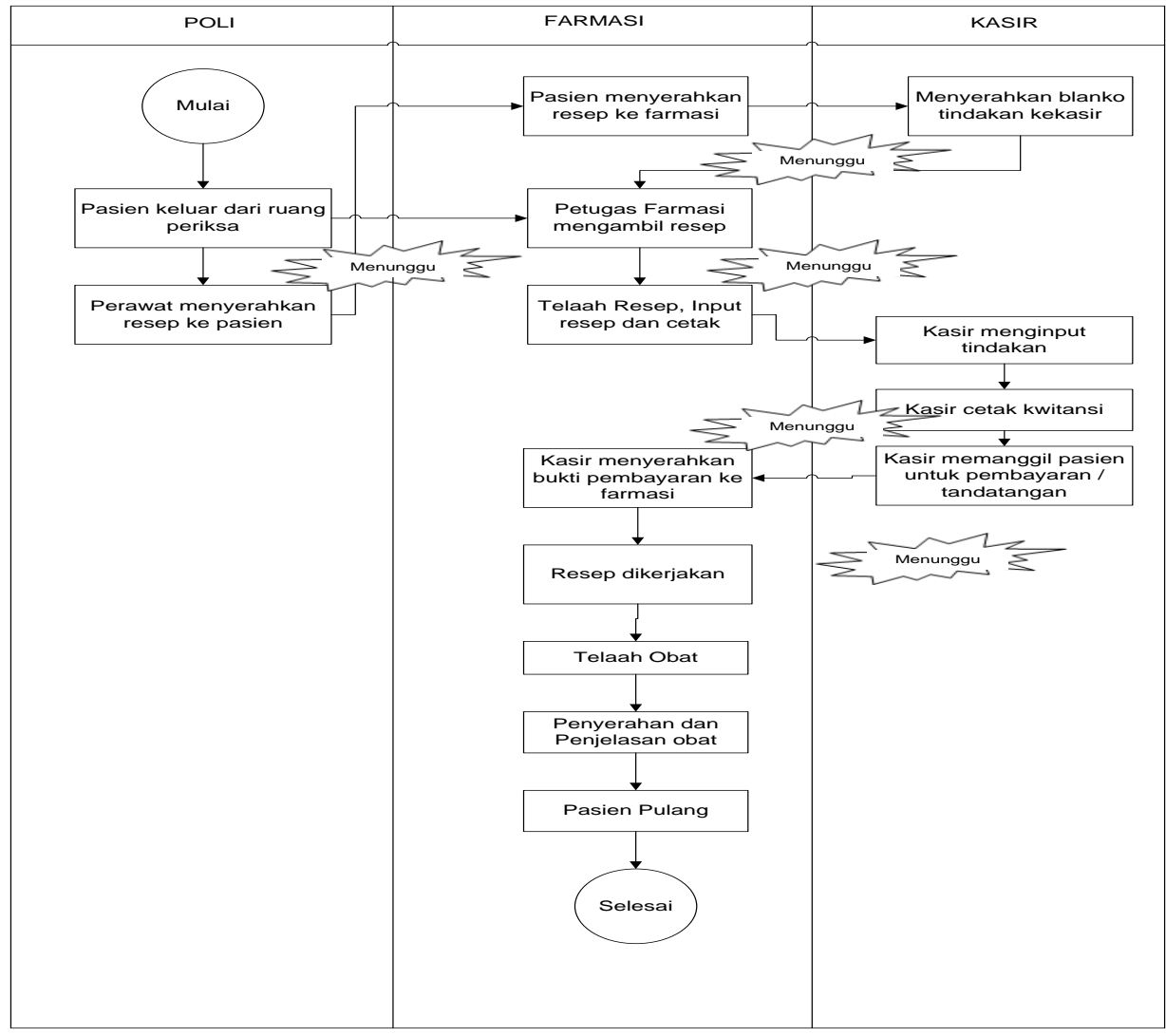

Gambar 1. Alur Proses Pelayanan Farmasi Rawat Jalan Dengan Waktu Tunggu 
Sumber: Dokumen SOP Farmasi RS Bali Jimbaran (2020)

Dari gambar alur di atas, peneliti akan melakukan pengamatan atau observasi yang akan dilakukan terhadap 15 orang pasien rawat jalan yang mendapatkan obat di poliklinik RSU Bali Jimbaran dan diberikan keterangan apakah kegiatan tersebut bersifat memberikan nilai tambah (value added) atau tidak memberikan nilai tambah/waste (non value added). Dari data yang dikumpulkan melalui observasi lapangan, didapatkan data kegiatan yang bersifat memberi nilai tambah kepada pasien (value added) dan tidak memberi nilai tambah (non value added) dipetakan dengan Value Stream Mapping, dimana dalam Lean tools, Value Stream Mapping (VSM) ini bertujuan untuk memetakan atau melihat keseluruhan proses yang ada di farmasi rawat jalan, secara visual sehingga akan lebih mudah dipahami proses demi proses kegiatan yang ada di alur pelayanan farmasi rawat jalan. Data yang didapatkan dilakukan penghitungan prosentase kegiatan yang bersifat value added dan waste (non value added). Ditampilkan juga diagram aliran proses (Sphageti Chart), yang berfungsi untuk melihat tata letak (Lay Out) dan arus aliran aktifitas, sehingga mendapatkan gambaran susunan tata ruang yang ada sekarang. Hasil observasi dapat disajikan dalam tabel di bawah ini. 
Tabel 2. Hasil Observasi Pasien Rawat Jalan

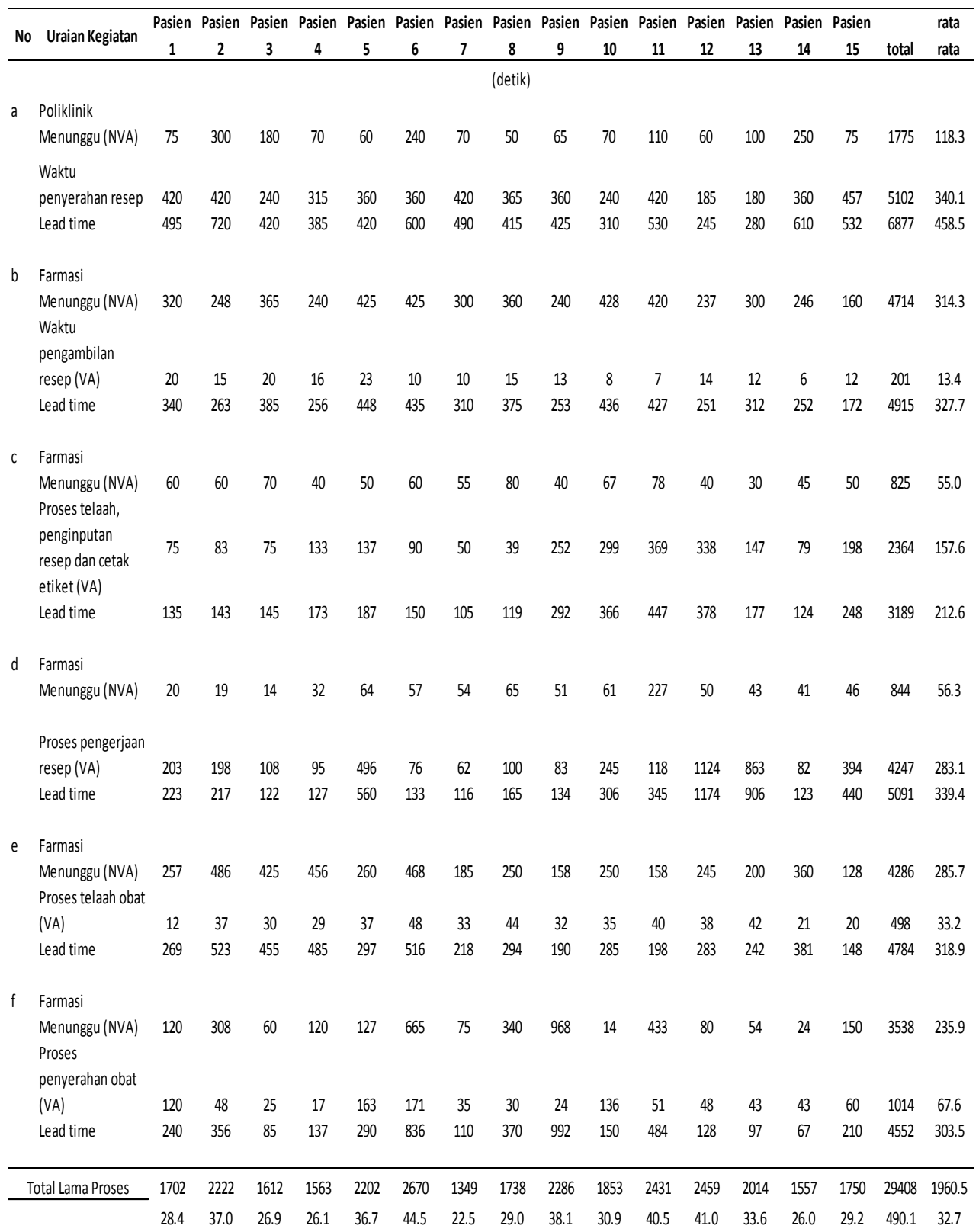

- Kegiatan 1 (Poliklinik), proses menunggu dimulai saat pasien selesai diperiksa dokter dan keluar dari ruangan poli. Pasien menunggu dokter selesai menulis resep diluar ruangan poli untuk diserahkan ke farmasi. Setelah resep diserahkan oleh perawat, pasien berjalan ke konter farmasi yang berjarak 15 meter.

- Kegiatan 2 (Farmasi), proses menunggu resep untuk diambil oleh petugas farmasi untuk ditelaah. Petugas farmasi yang mengambil resep didepan menyerahkan ke petugas yang menelaah resep di depan komputer. 
- Kegiatan 3 (Farmasi), proses menunggu dimulai dari resep sudah berada di petugas telaah resep dan masih menunggu antrian untuk ditelaah. Proses telaah dimulai dari mebaca resep dan dosis, aturan pakai dan menghitung dosis untuk resep racikan.

- Kegiatan 4 (Farmasi), pada proses ini tidak ada waktu tunggu, dikarenakan setelah resep ditelaah resep langsung diinput. Proses penginputan meliputi, input ke sistem, input etiket obat serta mencetak etiket, mengecek stok obat, konfirmasi ke dokter apabila ada penulisan resep dan dosis tidak jelas ataupun stok obat tidak ada. Konfirmasi ke bagian IKS (Ikatan Kerjasama), apabila budget obat melebihi, dan konfirmasi ke pasien apabila ada obat yang tidak ditanggung oleh bagian IKS.

- Kegiatan 5 (Farmasi), proses menunggu dimulai dari resep selesai diinput sampai resep diambil untuk dikerjakan. Proses pengerjaan resep non racikan dimulai dari pengambilan obat, memasukkan obat ke klip obat dan menempel etiket obat. Untuk resep racikan, menghitung ulang dosis racikan, proses pengambilan obat untuk racikan, proses meracik obat kemudian dimasukkan ke dalam cangkang kapsul atau kertas puyer atau ke pot salep untuk racikan salep. Kemudian dimasukkan ke klip obat dan dilakukan penempelan etiket.

- Kegiatan 6 (Farmasi), proses menunggu dimulai dari resep telah selesai dikerjakan sampai obat diambil untuk ditelaah oleh petugas farmasi lainnya. Proses telaah obat yaitu pengecekan kesesuaian antara obat dan resep meliputi nama pasien, nama obat, dosis, jumlah obat, aturan pakai.

- Kegiatan 7 (Farmasi), proses menunggu dimulai dari obat selesai ditelaah sampai obat diserahkan ke pasien. Penyerahan obat ke pasien merupakan pemberian KIE (Komunikasi Informasi dan Edukasi) ke pasien dengan menjelaskan fungsi obat, aturan pakai , tempat penyimpanan (untuk obat obat dengan syarat penyimpanan khusus,serta cara pakai obat (untuk penggunaan obat khusus). Diproses ini juga dilakukan pengoplosan obat untuk sirup kering. 
Waktu tunggu kegiatan diatas bertambah dikarenakan adanya permintaan obat dari IGD, sehingga petugas yang sedang berproses untuk pengerjaan resep harus terhenti karena melayani permintaan obat dari IGD. Total lama proses pelayanan di farmasi rawat jalan dari 15 pasien yang diamati, pasien yang diobservasi paling cepat adalah 1349 detik (22 menit 5 detik), yang paling lama adalah 2459 detik (41 menit). Jika dilihat dari rata-rata, maka pelayanan farmasi rawat jalan 1961 detik (32 menit 7 detik) mulai dari pasien keluar dari poliklinik sampai mendapatkan obat. Dari data tersebut di atas, kegiatan non value added yang paling tinggi adalah waktu tunggu proses pengambilan resep oleh tenaga farmasi, yaitu sebesar 314 detik (5 menit 2 detik).

\subsection{Identifikasi Value Added (VA) dan Non Value Added (NVA).}

Kegiatan value added (VA) dan non value added (NVA) dapat dilihat pada tabel di bawah ini.

Tabel 2. Prosentase Kegiatan Value Added (VA) dan Kegiatan Non Value Added (NVA)

\begin{tabular}{|c|c|c|c|c|c|c|c|}
\hline PROSES & 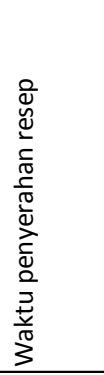 & 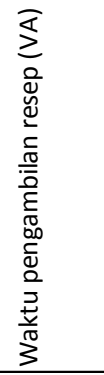 & 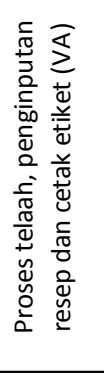 & 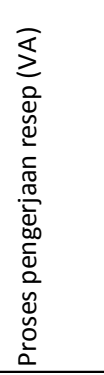 & 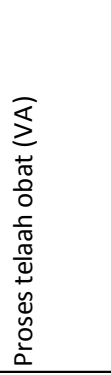 & 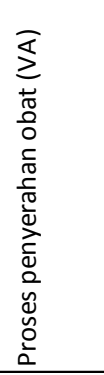 & 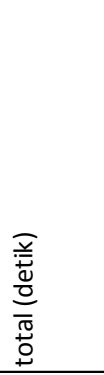 \\
\hline Total Non Value Added & 1775 & 4714 & 825 & 844 & 4286 & 3518 & 15962 \\
\hline Total Value Added & 5102 & 201 & 2364 & 4247 & 498 & 1014 & 13426 \\
\hline Total Lead Time & 6877 & 4915 & 3189 & 5091 & 4784 & 4552 & 29408 \\
\hline Presentase Value Added & \multicolumn{7}{|c|}{$13426 / 29408 \times 100 \%=45.65 \%$} \\
\hline Presentase Non Value Added & \multicolumn{7}{|c|}{$15962 / 29408 \times 100 \%=54.28 \%$} \\
\hline
\end{tabular}

Sumber: Data diolah, 2021

Pada gambar gambaran hasil value stream mapping yang di desain oleh peneliti melalui observasi yang dilakukan terhadap 15 pasien rawat jalan. Didapatkan pada Value Stream Mapping pelayanan farmasi rawat jalan, waktu proses (Cycle Time) yang paling cepat adalah waktu pengambilan resep di farmasi yaitu 13 detik dan waktu proses paling panjang saat penyerahan resep ke farmasi oleh pasien yaitu 340 
$\operatorname{detik}$ ( 5 menit 6 detik).

Jika dipetakan dalam value stream mapping dapat digambarkan sebagai berikut:

\subsection{Analisis Waste Pada Alur Pelayanan Farmasi Rawat Jalan.}

Berdasarkan identifikasi Value Added (VA) dan Non Value Added (NVA) yang sudah dilakukan dengan metode observasi, banyak ditemukan aktivitas yang bersifat NVA (waste). Dari 8 (delapan) jenis waste menurut metode lean, ditemukan 8 jenis waste di pelayanan farmasi rawat jalan RSU Bali Jimbaran. Waste terbanyak ditemukan pada waiting, yaitu sebanyak 7 waste, kemudian Defect dengan 2 waste, overproduction, transportation, inventory, motion, overprocessing dan human potential masing-masing ditemukan 1 waste. Jadi total waste yang teridentifikasi dan akan peneliti eliminasi dengan metode lean sebanyak 15 waste. Untuk lebih jelasnya, peneliti akan menjabarkan melalui tabel waste yang terdapat pada layanan farmasi rawat jalan di RSU Bali Jimbaran.

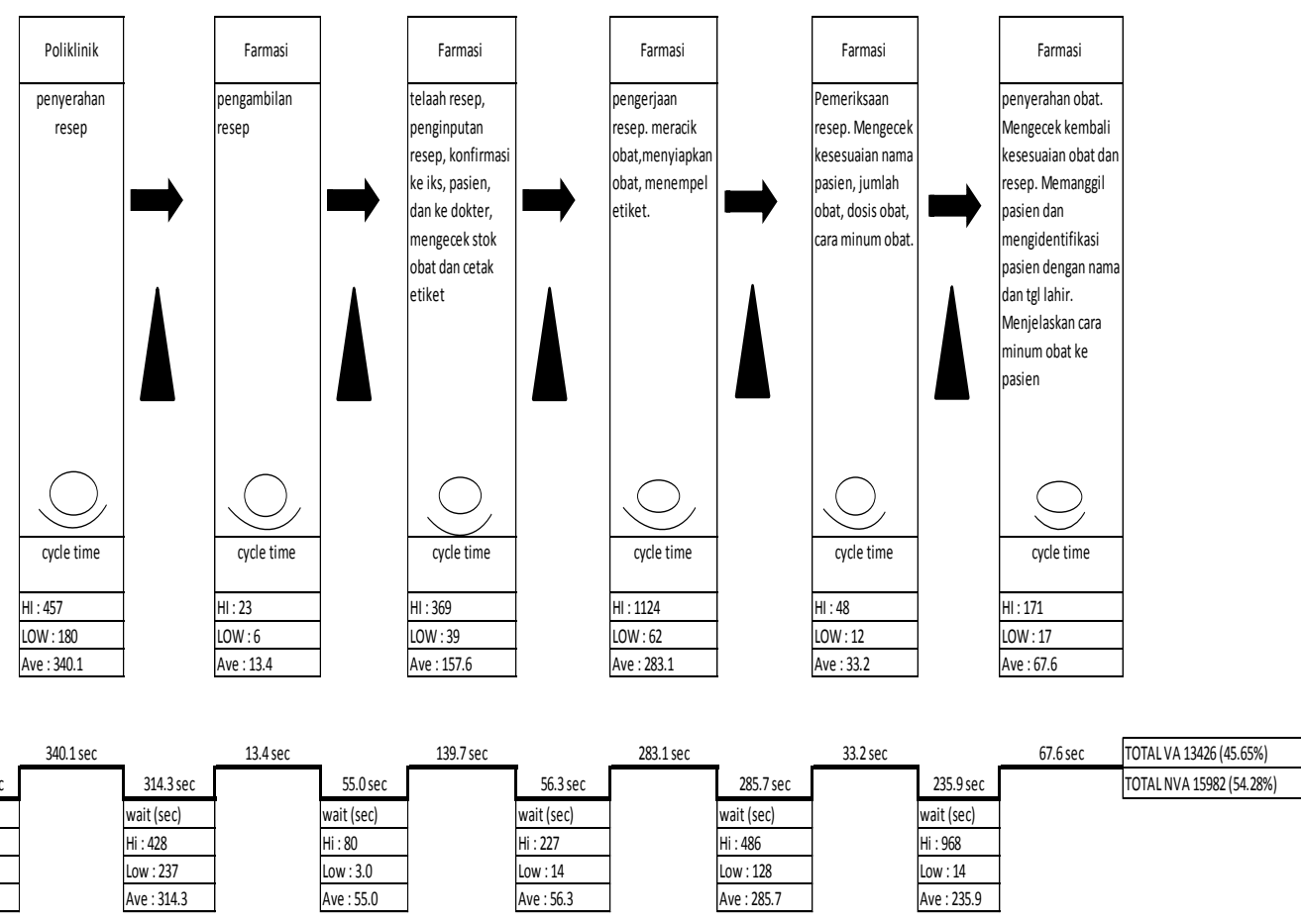

Gambar 2. Current State Value Stream Mapping Pelayanan Farmasi Rawat Jalan

\subsection{Identifikasi Masalah dengan RCA 5 W.}

Dari hasil observasi, wawancara yang mendalam terhadap petugas farmasi dan 
telaah dokumen yang ada, dilakukan analisis dengan metode Root Cause Analysis (RCA). Dari diagram 5 whys yang disajikan dari pertanyaan "mengapa waktu tunggu pelayanan farmasi rawat jalan lama?", peneliti memetakan beberapa pokok permasalahan yang muncul sebagai masalah utama dari waktu tunggu pelayanan farmasi rawat jalan yang lama. Terdapat 4 (empat) pokok faktor utama dari permasalahan yang ada, yaitu: beban kerja (Heijunka), tertib administrasi yang kurang, resep lama sampai ke farmasi dan Obat lama diserahkan. Faktor-faktor ini kemudian dikembangkan dengan metode 5 Whys, dan seterusnya sehingga penyebab-penyebab timbulnya masalah utama dapat diidentifikasi dan selanjutnya dilakukan eliminasi penyebab masalah dengan metode lean.

\subsection{Intervensi dengan Metode Lean.}

Beberapa intervensi akan dilakukan peneliti untuk memperbaiki mutu layanan di farmasi rawat jalan, yang diusulkan ke manajemen RSU Bali Jimbaran dengan metode lean. Dari manajemen menyetujui beberapa perubahan yang akan dilakukan antara lain memindahkan konter kasir, sehingga terpisah dengan konter farmasi; Merubah lay out farmasi rawat jalan; Membuat loket antara konter farmasi dengan ruang pengerjaan obat; Mengunci pintu ruang farmasi (hanya untuk petugas farmasi) dan dibuatkan loket untuk pengorderan obat dari IGD; Merubah alur pelayanan farmasi rawat jalan lebih efektif dan efisien.

\subsection{Implementasi Intervensi Alur Pelayanan Farmasi Rawat Jalan.}

\subsubsection{Memindahkan konter kasir, sehingga terpisah dengan konter farmasi.}

Awal proses yang dilakukan adalah pemisahan konter farmasi dengan kasir, sehingga antrian tidak berjubel, dan pasien dapat nyaman menunggu.

\subsubsection{Merubah lay out farmasi rawat jalan.}

Mengatur letak rak obat untuk mengurangi lalu lintas petugas yang berlebihan (transportasi). Rak injeksi dan rak alkes diletakkan dekat dengan pintu yang menuju ke IGD sehingga mempercepat gerak petugas saat ada permintaan obat injeksi dan alkes dari IGD. Menempatkan 2 tenaga di konter farmasi, dengan dua perangkat computer untuk mempercepat proses penginputan obat, dimana jika resep sudah selesai diinput, salah satu petugas membantu proses di dalam (penyediaan obat). 


\subsubsection{Membuat loket yang menghubungkan konter dengan ruang pengerjaan} obat.

Terdiri dari 2 loket, dimana loket pertama berfungsi untuk menyerahkan resep yang sudah di input ke dalam untuk dikerjakan. Loket ke dua berfungsi mentransfer obat yang sudah siap untuk bisa diberikan ke pasien

\subsubsection{Mengunci pintu ruang farmasi (hanya untuk petugas) dan dibuatkan}

\section{loket untuk pengorderan obat dari IGD.}

Mengunci ruang farmasi hanya untuk petugas, dan jika UGD datang untuk mengambil amprahan, cukup melalui loket untuk penyerahan resep, sehingga tidak mengganggu proses di farmasi, dan menghindari adanya obat yang terambil oleh perawat UGD, tapi tidak tercatat.

\subsubsection{Merubah alur pelayanan farmasi rawat jalan lebih efektif dan efisien.}

Setelah dilakukan perubahan di kasir maupun di farmasi, alur farmasi rawat jalan mulai diimplementasikan. Alur sesudah intervensi dapat dilihat pada gambar di bawah ini. Dari alur yang disajikan, dapat dilihat waiting yang bersifat type two waste dapat dihilangkan, dan type one waste dikurangi dan lama waktu kegiatan value added juga berkurang. Untuk memastikan alur tersebut lebih efektif dan efisien, maka peneliti kembali melakukan observasi untuk mengetahui waktu yang diperlukan pasien dalam siklus pelayanan farmasi rawat jalan. Pengukuran waktu dilakukan sama dengan pengukuran waktu saat current state.

\subsection{Outcome.}

Dari semua implementasi intervensi yang sudah dilakukan, dan observasi yang dilakukan peneliti terhadap 15 pasien rawat jalan poliklinik untuk mengukur kembali lama waktu pelayanan pasien dan melihat VA dan NVA yang ada, dapat dilihat pada tabel berikut. Dari tabel, terjadi penurunan waktu pelayanan pasien sebelum dan sesudah intervensi, dimana sebelum intervensi, pasien membutuhkan waktu dalam satu siklus pelayanan rata-rata 32,7 menit, menjadi rata-rata 9,1 menit setelah implementasi intervensi. 


\subsection{Perbaikan Waktu Tunggu.}

Perbaikan waktu tunggu terlihat dari semua waktu layanan, mulai awal sampai akhir layanan di farmasi rawat jalan. Rata-rata waktu yang dibutuhkan 1 pasien untuk mendapatkan layanan selama 9,1 menit. Jika dilihat perbandingan prosentase kegiatan VA dan NVA, terjadi peningkatan kegiatan VA menjadi $81,72 \%$, dan penurunan kegiatan NVA menjadi $18,28 \%$.

\section{Hasil Dan Pembahasan}

Hasil penelitian yang didapatkan serta hasil intervensi yang dilakukan kemudian dikaitkan dengan teori-teori yang ada dan penelitian - penelitian yang sama yang sudah pernah dilakukan sebelumnya.

\subsection{Current State Visual Stream Mapping Farmasi Rawat Jalan dan Implementasi Intervensi.}

Menggunakan value stream, akan terlihat pemborosan yang terdapat di berbagai tahap proses produksi barang dan jasa. Proses yang mengalir disini sebagai inti dari organisasi lean, yaitu mempersingkat waktu yang diperlukan mulai dari awal produksi hingga menjadi suatu produk, memberikan nilai tambah kepada konsumen, memunculkan kualitas terbaik, biaya rendah dan waktu pengiriman yang singkat dan tepat waktu. Berdasarkan hasil penelitian yang terlihat pada gambar 4.5 mengenai current state value stream mapping farmasi rawat jalan, didapatkan bahwa 45,65\% kegiatan bersifat value added (VA) dan 54,28\% kegiatan di farmasi rawat jalan bersifat non value added (NVA), hal ini menunjukkan bahwa kegiatan pelayanan di farmasi rawat jalan saat ini belum memberikan nilai tambah bagi pasien dan belum menunjukkan mutu layanan yang ada di farmasi rawat jalan RSU Bali Jimbaran. Setelah diimplementasikan intervensi yang dilakukan, didapatkan kegiatan yang bersifat Value Added sebesar 81,72\% dan kegiatan yang bersifat Non Value Added sebesar 18,28\%. Untuk lebih jelasnya seperti tabel di bawah. 
Relasi : Jurnal Ekonomi, Vol. XVIII, No. 1, Januari 2022, pp. 101-131

Tabel 5. Observasi Pasien Rawat Jalan setelah Implementasi Intervensi

\begin{tabular}{|c|c|c|c|c|c|c|c|c|c|c|c|c|c|c|c|c|c|c|}
\hline No & o Uraian Kegiatan & $\begin{array}{c}\text { Pasien } \\
1 \\
\end{array}$ & $\begin{array}{c}\text { Pasien } \\
2 \\
\end{array}$ & $\begin{array}{c}\text { Pasien } \\
\mathbf{3} \\
\end{array}$ & $\begin{array}{c}\text { Pasien } \\
4 \\
\end{array}$ & $\begin{array}{c}\text { Pasien } \\
5 \\
\end{array}$ & $\begin{array}{c}\text { Pasien } \\
6 \\
\end{array}$ & $\begin{array}{c}\text { Pasien } \\
7 \\
\end{array}$ & $\begin{array}{c}\text { Pasien } \\
8 \\
\end{array}$ & $\begin{array}{c}\text { Pasien } \\
9 \\
\end{array}$ & $\begin{array}{c}\text { Pasien } \\
10 \\
\end{array}$ & $\begin{array}{c}\text { Pasien } \\
11 \\
\end{array}$ & $\begin{array}{c}\text { Pasien } \\
12 \\
\end{array}$ & $\begin{array}{c}\text { Pasien } \\
13\end{array}$ & $\begin{array}{c}\text { Pasien } \\
14 \\
\end{array}$ & $\begin{array}{c}\text { Pasien } \\
15 \\
\end{array}$ & total & $\begin{array}{l}\text { rata } \\
\text { rata }\end{array}$ \\
\hline & & & & & & & & & (detik) & & & & & & & & & \\
\hline \multirow[t]{5}{*}{ a } & Poliklinik & & & & & & & & & & & & & & & & & \\
\hline & Menunggu (NVA) & 0 & 0 & 0 & 0 & 0 & 0 & 0 & 0 & 0 & 0 & 0 & 0 & 0 & 0 & 0 & 0 & 0.0 \\
\hline & Waktu & & & & & & & & & & & & & & & & & \\
\hline & penyerahan resep & 30 & 40 & 24 & 25 & 28 & 30 & 35 & 33 & 44 & 45 & 31 & 25 & 38 & 20 & 25 & 473 & 31.5 \\
\hline & Lead time & 30 & 40 & 24 & 25 & 28 & 30 & 35 & 33 & 44 & 45 & 31 & 25 & 38 & 20 & 25 & 473 & 31.5 \\
\hline \multirow[t]{5}{*}{ b } & Farmasi & & & & & & & & & & & & & & & & & \\
\hline & Menunggu (NVA) & 0 & 0 & 0 & 0 & 0 & 0 & 0 & 0 & 0 & 0 & 0 & 0 & 0 & 0 & 0 & 0 & 0.0 \\
\hline & $\begin{array}{l}\text { Waktu } \\
\text { pengambilan }\end{array}$ & & & & & & & & & & & & & & & & & \\
\hline & resep (VA) & 5 & 7 & 3 & 2 & 5 & 6 & 3 & 4 & 5 & 5 & 2 & 3 & 2 & 3 & 5 & 60 & 4.0 \\
\hline & Lead time & 5 & 7 & 3 & 2 & 5 & 6 & 3 & 4 & 5 & 5 & 2 & 3 & 2 & 3 & 5 & 60 & 4.0 \\
\hline \multirow[t]{4}{*}{ c } & Farmasi & & & & & & & & & & & & & & & & & \\
\hline & Menunggu (NVA) & 10 & 15 & 19 & 20 & 23 & 22 & 21 & 18 & 15 & 17 & 20 & 24 & 23 & 10 & 13 & 270 & 18.0 \\
\hline & $\begin{array}{l}\text { Proses telaah, } \\
\text { penginputan } \\
\text { resep dan cetak } \\
\text { etiket (VA) }\end{array}$ & 75 & 93 & 75 & 113 & 137 & 90 & 50 & 41 & 253 & 316 & 375 & 462 & 147 & 79 & 199 & 2505 & 167.0 \\
\hline & Lead time & 85 & 108 & 94 & 133 & 160 & 112 & 71 & 59 & 268 & 333 & 395 & 486 & 170 & 89 & 212 & 2775 & 185.0 \\
\hline \multirow[t]{5}{*}{ d } & Farmasi & & & & & & & & & & & & & & & & & \\
\hline & Menunggu (NVA) & 0 & 0 & 0 & 0 & 0 & 0 & 0 & 0 & 0 & 0 & 0 & 0 & 0 & 0 & 0 & 0 & 0.0 \\
\hline & Proses pengerjaan & & & & & & & & & & & & & & & & & \\
\hline & resep (VA) & 153 & 135 & 108 & 95 & 235 & 76 & 62 & 100 & 83 & 245 & 118 & 139 & 354 & 82 & 394 & 2379 & 158.6 \\
\hline & Lead time & 153 & 135 & 108 & 95 & 235 & 76 & 62 & 100 & 83 & 245 & 118 & 139 & 354 & 82 & 394 & 2379 & 158.6 \\
\hline \multirow[t]{5}{*}{ e } & Farmasi & & & & & & & & & & & & & & & & & \\
\hline & Menunggu (NVA) & 25 & 30 & 27 & 33 & 21 & 15 & 17 & 28 & 24 & 23 & 28 & 16 & 18 & 13 & 18 & 336 & 22.4 \\
\hline & Proses telaah obat & & & & & & & & & & & & & & & & & \\
\hline & (VA) & 10 & 25 & 23 & 28 & 21 & 16 & 18 & 24 & 17 & 14 & 17 & 20 & 23 & 19 & 26 & 301 & 20.1 \\
\hline & Lead time & 35 & 55 & 50 & 61 & 42 & 31 & 35 & 52 & 41 & 37 & 45 & 36 & 41 & 32 & 44 & 637 & 42.5 \\
\hline \multirow[t]{5}{*}{$\mathrm{f}$} & Farmasi & & & & & & & & & & & & & & & & & \\
\hline & Menunggu (NVA) & 60 & 55 & 58 & 65 & 63 & 59 & 75 & 70 & 45 & 48 & 58 & 59 & 67 & 63 & 48 & 893 & 59.5 \\
\hline & $\begin{array}{l}\text { Proses } \\
\text { penyerahan obat }\end{array}$ & & & & & & & & & & & & & & & & & \\
\hline & (VA) & 120 & 48 & 25 & 17 & 163 & 160 & 35 & 30 & 24 & 115 & 51 & 48 & 43 & 45 & 60 & 984 & 65.6 \\
\hline & Lead time & 180 & 103 & 83 & 82 & 226 & 219 & 110 & 100 & 69 & 163 & 109 & 107 & 110 & 108 & 108 & 1877 & 125.1 \\
\hline \multirow{2}{*}{\multicolumn{2}{|c|}{ Total Lama Proses }} & 488 & 448 & 362 & 398 & 696 & 474 & 316 & 348 & 510 & 828 & 700 & 796 & 715 & 334 & 788 & 8201 & 546.73 \\
\hline & & 8.1 & 7.5 & 6.0 & 6.6 & 11.6 & 7.9 & 5.3 & 5.8 & 8.5 & 13.8 & 11.7 & 13.3 & 11.9 & 5.6 & 13.1 & 136.7 & 9.1 \\
\hline
\end{tabular}

Sumber: Data diolah, 2021 
Tabel 6.. Prosentase Kegiatan VA dan NVA setelah Implementasi Intervensi

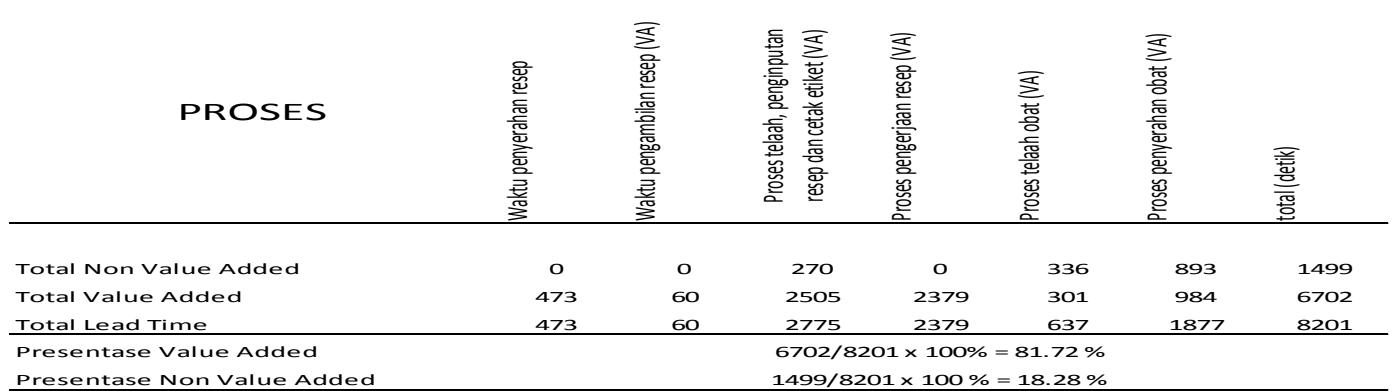

Sumber: Data diolah, 2021

Perbaikan proses layanan farmasi rawat jalan RSU Bali Jimbaran dapat dilihat pada gambar di bawah ini.

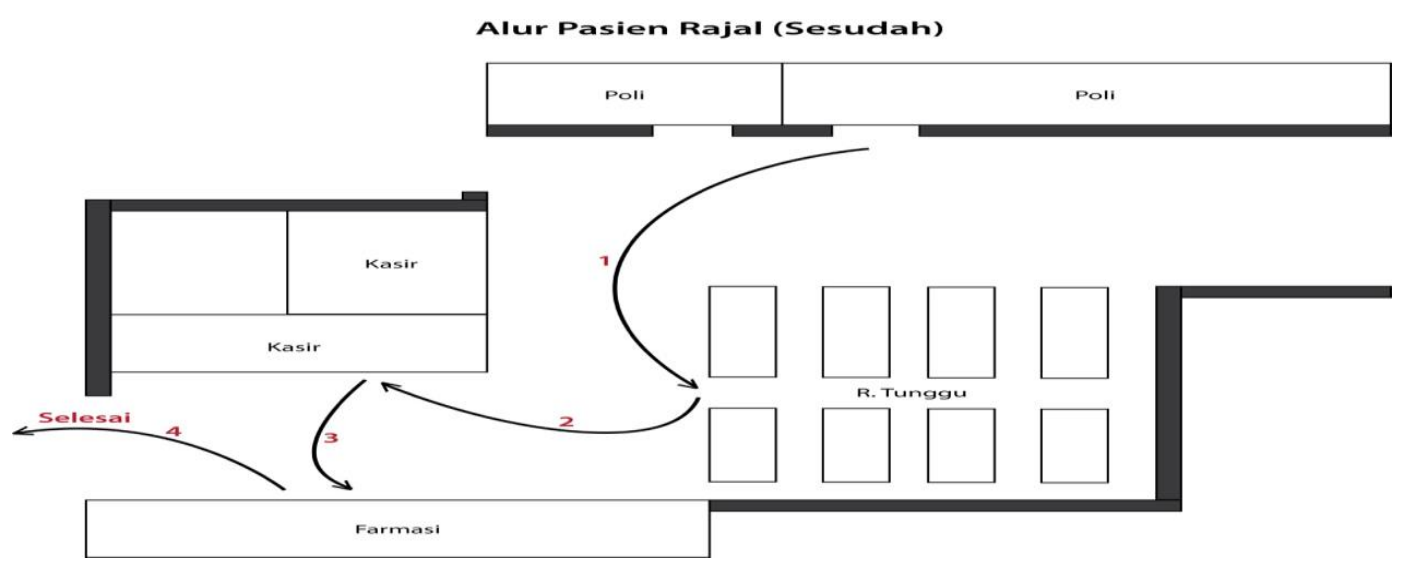

Gambar 2.Diagram Sphagetty Aktivitas Pasien setelah Implementasi Intervensi

Sumber: Data diolah, 2021

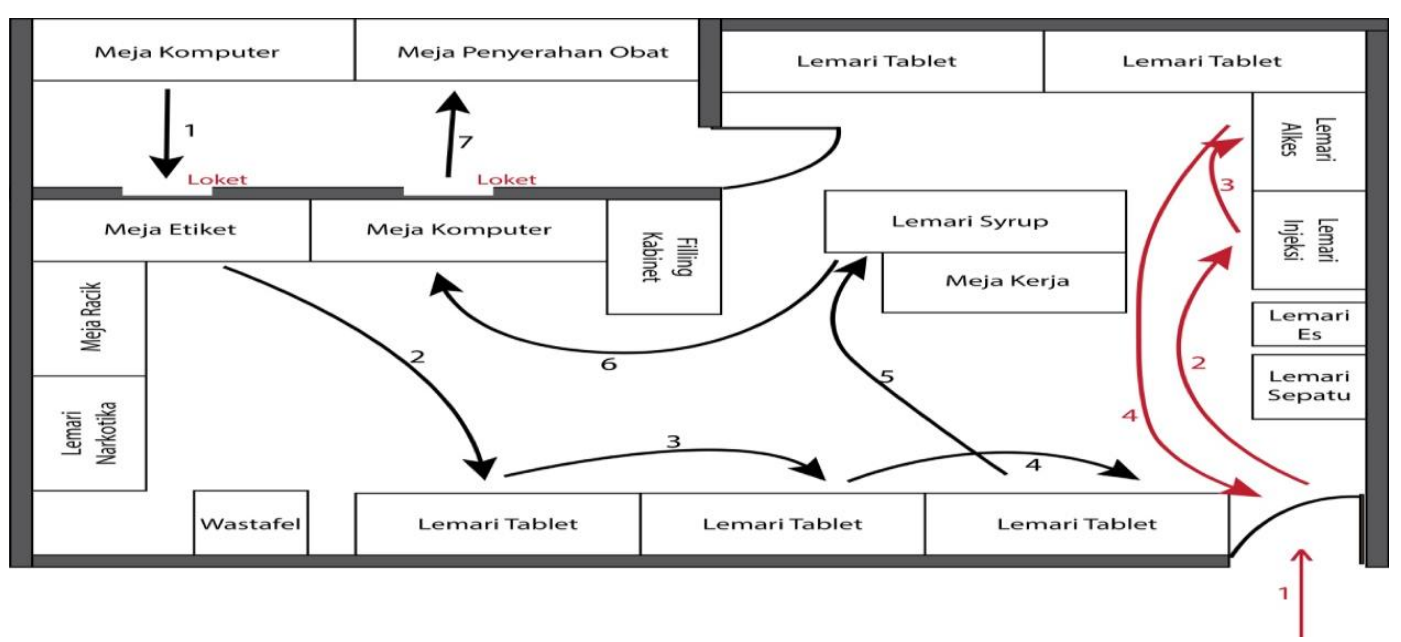

Gambar 3. Diagram Sphagetty Aktivitas Petugas setelah Implementasi Intervensi Sumber: Data diolah, 2021 


\subsection{Analisis Waste dan Implementasi Intervensi.}

Tujuan lean adalah peningkatan terus menerus customer value melalui identifikasi value added dan non value added yang tidak memberikan nilai tambah yang merupakan pemborosan (waste). Kegiatan yang dilakukan adalah menganalisa waste (pemborosan) sehingga dapat dieliminasi. Ada 8 tipe waste menurut teori Graban (2012), yaitu: Defect, Overproduction, Transportation, Waiting, Inventory, Motion, Overprocessing dan Human Potential. Pada penelitian ini, penulis menemukan adanya ke delapan tipe waste tersebut, dimana waste terbanyak ditemukan pada waiting, yaitu sebanyak 7 waste, yaitu : Pasien menunggu dokter selesai menulis resep di luar ruang periksa, kemudian dilakukan perbaikan dengan cara, pasien langsung menunggu obat di farmasi, karena resep akan dibawakan langsung oleh perawat ke farmasi. Resep menunggu di konter farmasi untuk diambil oleh petugas farmasi yang sedang bertugas di dalam. Metode perbaikan yang dilakukan adalah pembuatan loket antara konter farmasi dengan tempat penyiapan obat dan mengatur tenaga farmasi untuk bertugas di luar saat-saat jam sibuk. Resep menunggu untuk diinput, Resep menunggu untuk dikerjakan dan obat menunggu untuk di telaah, karena petugas IGD langsung masuk ke farmasi dan mengambil obat sendiri, menyebabkan lalu lintas di farmasi menjadi krodit. Hal ini tentunya akan mengganggu aktifitas petugas farmasi, terutama di jam-jam sibuk. Perbaikan yang dilakukan adalah pintu farmasi dikunci, dibuatkan loket sehingga petugas IGD tidak bisa lalu lalang ke farmasi, dan lay out penempatan obat injeksi dan alkes didekatkan ke pintu, sehungga memudahkan petugas farmasi mengambilnya. (Yang paling sering diamprah IGD adalah alkes dan obat injeksi) . Antrean obat untuk diserahkan, karena tempat masih bergabung dengan kasir, sehingga petugas farmasi yang bisa menyerahkan hanya 1 petugas. Perbaikan yang dilakukan dengan memisahkan konter farmasi dengan kasir. Pasien menunggu obat sambil berdiri, karena kekurangan tempat duduk di depan konter farmasi dan kasir. Hal perbaikan yang dilakukan dengan memisahkan kasir dan farmasi, dan pasien menunggupun terpisah, tidak berjubel berdesakan dalam satu lokasi. Defect dengan 2 waste yaitu pertama, mesin printer etiket obat yang sering eror, dikarenakan software printer yang tidak konek dengan program windows baru. Perbaikan yang 
sudah dilakukan dengan mencari software yang sesuai. Kedua, hutang obat pasien, dimana stok obat kurang, sehingga pasien tidak membawa keseluruhan obat yang harusnya didapat pasien. Setelah obat ada, baru petugas farmasi yang akan membawakan obat tersebut ke rumah pasien. Perbaikan yang dilakuakan dengan menggunakan kartu Kanban untuk manajemen stok.

Sedangkan waste overproduction, transportation, inventory, motion, overprocessing dan human potential masing-masing ditemukan 1 waste. Jadi total waste yang teridentifikasi dan akan peneliti eliminasi dengan metode lean sebanyak 15 waste. Waste pada pelayanan farmasi rawat jalan dapat dilihat pada tabel 6.3 sampai dengan tabel 6.10. Ke lima belas waste yang ditemukan, ada yang bersifat waste tipe 1, seperti resep menuggu untuk di telaah, obat yang menunggu juga untuk di telaah, dimana proses ini saat ini harus tetap dikerjakan untuk pengecekan kebenaran obat yang akan diberikan kepada pasien, tetapi waktunya dapat dikurangi.

\subsection{Analisis Akar Masalah.}

Pada penelitian ini, pada gambar 6.11 di identifikasi terhadap masalah utama yang menjadi penyebab situasi unlean, waste dan aktivitas non value added (NVA) ditemukan 4 (empat) pokok faktor utama dari permasalahan yang ada, yaitu: beban kerja (Heijunka), tertib administrasi yang kurang, resep lama sampai ke farmasi dan Obat lama diserahkan. Analisis lebih lanjut terhadap permasalahan yang dilakukan melalui proses RCA, menyimpulkan belum adanya metode penyimpanan obat, SIM RS yang belum bisa mengadopsi bentuk resep ke bentuk elektronik resep, petunjuk arah yang belum ada, konter farmasi yang masih bergabung menjadi satu tempat dengan kasir, yang keseluruhannya akan ditindaklanjuti melalui intervensi dengan penerapan metode lean.

\subsection{Implementasi Intervensi dengan Menerapkan Metode Lean.}

Pada penelitian ini, metode lean yang peneliti terapkan yaitu 5 S, Kanban dan Visual Management. Penerapannya dijabarkan sebagai berikut:

\subsubsection{Implementasi $5 \mathrm{~S}$.}

Menciptakan suasana kerja dan lingkungan yang bersih, nyaman dan teratur sehingga memudahkan petugas dalam melakukan pekerjaannya, maka peneliti 
memilih metode $5 \mathrm{~S}$ di pelayanan farmasi rawat jalan dikarenakan sepanjang pengamatan peneliti merupakan masalah besar rangkaian pelayanan di farmasi rawat jalan. Langkah-langkah yang dilakukan dalam penerapan $5 \mathrm{~S}$ berturut-turut sebagai berikut, pertama Seiri/Sort/Ringkas. Menyingkirkan barang-barang yang sudah tidak diperlukan lagi, sehingga memudahkan dalam bekerja. Menggalakkan penggunaan resep elektronik, sehingga dapat mengurangi berkas dari resep. Kedua, Seiton/Store/Rapi. Menyusun barang-barang yang sering digunakan di tempat yang mudah dijangkau sehingga memudahkan setiap petugas untuk mengambilnya. Semua barang yang digunakan diletakkan di tempat yang sudah disediakan. Memberikan label/tanda tempat penyimpanan, sehingga semua petugas tahu. Ketiga, Seiso/Shine/Resik. Menciptakan lingungan kerja yang bersih dan rapi. Menghilangkan debu yang menempel pada barang dan tempat kerja, sehingga kesehatan petugas dapat terjaga dan meningkatkan semangat kerja.

Keempat, Seiketsu/Standardize/Rawat. Semua kegiatan di layanan farmasi rawat jalan terukur dengan baik, sehingga tidak ada lagi kegiatan yang bersifat overprocessing, yang nantinya akan mengurangi waktu tunggu pasien. Tetap meyakinkan ketiga $\mathrm{S}$ pertama sudah dilakukan dan menjadi budaya kerja di farmasi rawat jalan. Membuat peraturan ditempel untuk meletakkan alat kerja di tempat yang sudah disediakan. Kelima, Shitsuke/Sustain/Rajin. Menjadikan seluruh SPO (Standar Prosedur Operasional) yang sudah baik merupakan kebiasaan dalam bekerja, yang nantinya akan menjadi budaya kerja di farmasi rawat jalan RSU Bali Jimbaran.

\subsection{Menerapkan Kanban.}

Salah satu penyebab waktu tunggu di farmasi lama, adalah obat yang tidak ada di farmasi rawat jalan, karena keterlambatan pemesanan ke gudang atau gudang yang sedang kosong. Salah satu perubahan yang dilakukan adalah penerapan kartu Kanban, sehingga memudahkan pemantauan stok dan mengurangi defect. Dengan keterangan yang ada pada kartu Kanban tersebut, siapapun dapat melakukan pemesanan berikutnya. Tidak diperlukan staf dengan keterampilan dan pengalaman khusus tentang pengadaan barang. Karena semua keterangan yang dibutuhkan sudah terdapat pada kartu itu begitu kartu Kanban itu muncul. Kemudian dibuatkan 
kotak kartu Kanban pemesanan. Kotak Kanban ini berguna untuk meletakkan kartu yang muncul. Jadi setiap kartu Kanban muncul disetiap barang, maka petugas yang melihatnya langsung meletakkan kartu ini di kotak Kanban. Petugaspun dapat langsung meletakkan karena di bawah kartu Kanban tertulis " Letakkan Kartu Ini di Kotak Kanban”. Semua jenis barang, yang sudah terlihat kartunya, akan diletakkan di kotak Kanban yang akan diorder.. Kotak kartu Kanban diletakkan di atas meja, sehingga memudahkan petugas melakukan pengorderan melalui sistem informasi Rumah Sakit (SIM RS). Setelah melakukan pengorderan maka kartu Kanban akan dipindahkan dari kotak Kanban akan diorder ke kotak Kanban sudah disorder. Setelah petugas farmasi melakukan pengorderan melalui sistem, maka petugas gudang akan menyiapkan orderan dan mengirimkannya ke farmasi rawat jalan. Selanjutnya, setelah barang yang dipesan datang, dilakukan serah terima antara petugas gudang dan petugas farmasi rawat jalan. Barang diletakkan pada tempatnya dan kartu Kanban dikembalikan ke posisi semula sesuai keterangan kartu tersebut. Dan dengan kembalinya kartu Kanban ke tempat semula, maka selesailah satu siklus pemesanan barang.

\subsection{Visual Management.}

Salah satu visual management yang dilakukan perbaikan adalah memberikan tanda yang jelas pada setiap ruangan dan konter, sehingga pasien bisa menemukan dengan mudah tempat atau lokasi yang dituju pasien. Sedangkan intervensi SIM RS belum bisa diimplementasikan saat ini, karena biayanya dianggarkan pada budgeting periode tahun 2019, jadi program yang bersifat jangka menegah.

\subsection{Merubah Alur Proses Pelayanan Farmasi Rawat Jalan.}

Setelah dilakukan perubahan di kasir maupun di farmasi, alur farmasi rawat jalan mulai diimplementasikan. Alur sebelum dan sesudah perbaikan dapat dilihat pada gambar 4 .

Dari bagan alur tersebut, dapat dijelaskan proses pelayanan farmasi rawat jalan.

1. Pasien yang sudah selesai melakukan pemeriksaan di masing-masing poliklinik, keluar dari ruang pemeriksaan menunggu resep yang akan diserahkan perawat ke pasien, kemudian pasien membawa resep ke farmasi 
untuk diserahkan ke konter farmasi dan menyerahkan blangko tindakan ke kasir. Konter farmasi dan kasir di satu tempat yang sama, proses menunggu dimulai saat pasien selesai diperiksa dokter dan keluar dari ruangan poli. Pasien menunggu dokter selesai menulis resep diluar ruangan poli untuk diserahkan ke farmasi. Setelah resep diserahkan oleh perawat, pasien berjalan ke konter farmasi yang berjarak 15 meter. Pasien sering kebingungan mencari tempat farmasi, karena penunjuk arah yang tidak jelas dan antrian yang berjubel karena untuk penyerahan resep, pengambilan obat dan pembayaran di kasir. Kemudian alur dirubah menjadi perawat membawa resep ke farmasi dan sekaligus mengantar pasien ke ruang tunggu farmasi.

2. Pasien menyerahkan resep ke petugas dan di letakkan pada wadah khusus yang sudah disediakan. Proses menunggu disini yaitu menunggu resep untuk diambil oleh petugas farmasi untuk ditelaah. Petugas farmasi yang mengambil resep didepan menyerahkan ke petugas yang menelaah resep di depan komputer. Perubahan alur yang dilakukan dengan membuat loket antara konter farmasi dan ruang pengolahan obat, sehingga mengurangi over transportasi petugas farmasi.

3. Petugas farmasi mengambil resep, kemudian dilakukan telaah terhadap resep, sekaligus menginput resep ke sistem dan cetak etiket. Jika obat sudah terinput, pasien dipanggil kasir untuk melakukan pembayaran, kemudian pasien duduk lagi untuk menunggu obat. Proses menunggu yaitu pasien menunggu farmasi mengerjakan obat. Perubahan yang dilakukan, setelah farmasi menginput obat, obat langsung dikerjakan.

4. Melakukan telaah obat, kemudian di cek oleh petugas yang lain dan ditanda tangani, sebagai bukti obat sudah di cek dan benar. Proses menunggu dimulai dari resep telah selesai dikerjakan sampai obat diambil untuk ditelaah oleh petugas farmasi lainnya. Proses telaah obat yaitu pengecekan kesesuaian antara obat dan resep meliputi nama pasien, nama obat, dosis, jumlah obat, aturan pakai. Inilah waste type one, yang belum bisa dihilangkan, tetapi sudah bisa dikurangi waktunya. 
5. Petugas farmasi memanggil pasien untuk menyerahkan obat dan menjelaskan aturan pakainya.

6. Setelah pasien menerima obat, pasien pulang.

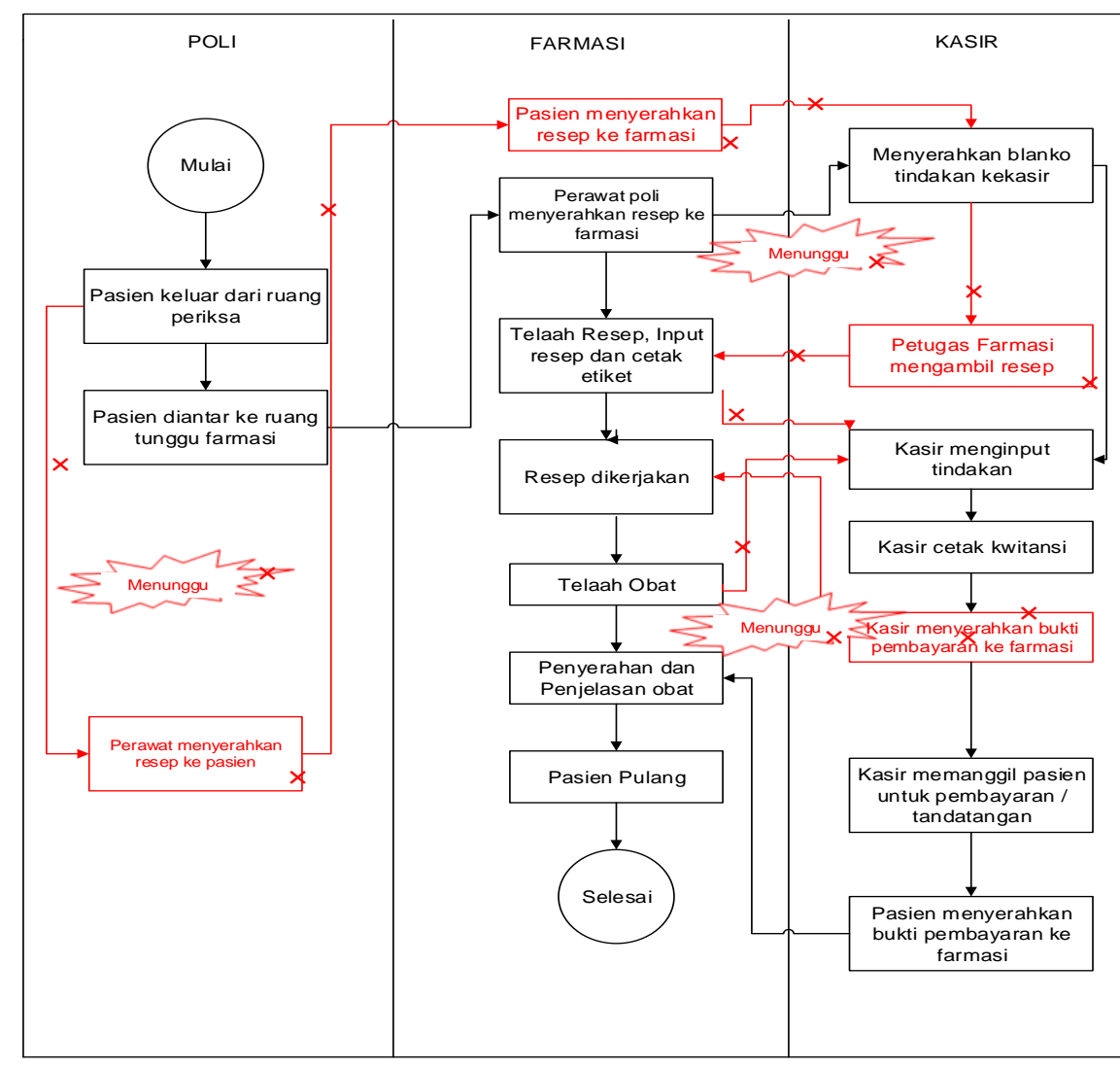

Gambar 4. Alur Proes Pelayanan Farmasi Rawat Jalan Sebelum dan Sesudah Intervensi.

Sumber: Data diolah, 2021

Disetiap alur proses yang ada, seringkali proses tersebut tertunda, oleh karena petugas melayani permintan obat dari petugas IGD yang langsung bisa masuk ke ruang farmasi. Rata-rata 15 kali dalam satu shift jaga. Dengan adanya loket di pintu farmasi, hal ini sudah bisa dieliminasi. 


\subsection{Perbaikan Waktu Tunggu.}

Teori yang terdapat pada Graban (2012), secara definisi lean diartikan sebagai kurus (ramping), Lean didefinisikan sebagai seperangkat peralatan (tools set), sistem manajemen dan metedologi yang dapat mengubah rumah sakit dalam mengatur dan mengelola sehingga mengurangi kesalahan, mengurangi waktu tunggu, menghilangkan semua hambatan dan mendukung kegiatan dokter dan karyawan yang bertujuan meningkatkan kualitas pelayanan dan perawatan pasien. Dari hasil penelitian ini, didapatkan pada tabel 4.12, banyak kegiatan NVA yang dapat dieliminasi sebesar 66\% dan kegiatan VA menunjukkan peningkatan sebesar 44\%. Dengan banyaknya kegiatan yang bersifat VA dan di eliminasinya kegiatan NVA, akan mempercepat proses pelayanan farmasi rawat jalan di RSU Bali Jimbaran. Hal seperti ini juga sejalan dengan penelitian sebelumnya yaitu penelitian Novantri (2016) di RSUD Dr.H.M. Rabain Kabupaten Muara Enim, diperoleh cycle time diperpendek 16,4\% dan eliminasi waste sebear 98\%. Penelitian oleh Valentino (2017) di Rumah Sakit RK Charitas Palembang menunjukkan adanya perbaikan berupa eliminasi waste di IGD dari 38 kegiatan menjadi 29 kegiatan dan value added activity meningkat sebesar 17,97\% dan penelitian Noviani (2017) di Rumah Sakit Hermina Depok, ditemukan Non value added (waste) pasien sebesar 90\%, sedangkan kegiatan value added nya hanya $10 \%$.

\subsection{Perbaikan Kepuasan Pelanggan.}

Menurut teori Donabedian (1980) Mutu merupakan nilai yang dimiliki oleh suatu produk atau layanan. Sesuai dengan konsep mutu, dapat disampaikan bahwa mutu pelayanan kesehatan merupakan hsail akhir (outcome) dari interaksi atau hubungan antara berbagai aspek, komponen atau unsur dari organisasi pelayanan kesehatan yang membentuk seuatu sistem. Jika mutu pelayanan sudah baik, tentunya dapat meningkatkan kepuasan pelanggan. Salah satu cara yaitu penerapan lean thinking, untuk senantiasa secara terus menerus memberikan nilai tambah kepada pasien. Pada penelitian ini, saat telaah dokumen dari unit hubungan pelanggan RSU Bali Jimbaran, terjadi penurunan keluhan pelanggan sebear 50\%. 


\section{Kesimpulan}

Beberapa kesimpulan yang didapat pada penelitian ini antara lain analisis terhadap current state value stream mendapatkan bahwa alur proses yang memiliki value added 45,65\% dan non value added (waste) sebesar 54,28\%. Waktu tunggu farmasi rawat jalan pada current state didapatkan rata-rata 32,7 menit. Terjadi bottle neck saat pasien menyerahkan resep ke farmasi. Waktu yang dibutuhkan sampai menyerahkan resep ke farmasi merupakan waktu terlama yaitu rata-rata 5,6 menit. Hal ini dikarenakan pasien sulit menemukan konter farmasi, dan ketika sudah menemukan konter farmasi, pasien harus menunggu menyerahkan resep ke farmasi, karena antrean yang berjubel, untuk pelayanan farmasi dan kasir, oleh karena konter farmasi dan kasir masih dalam satu tempat.Analisis terhadap alur proses pelayanan farmasi rawat jalan, dapat diidentifikasi 8 jenis waste. Terdapat empat permasalahan utama yang menyebabkan terjadinya waste pada proses pelayanan farmasi rawat jalan yaitu beban kerja (Heijunka), Tertib administrasi yang kurang, Resep lama sampai ke farmasi, Obat lama diserahkan ke pasien.

Kemudian digali lebih lanjut dengan melakuakn Root Cause Analysis (RCA) yang akan dilakukan intervensi perbaikannya adalah belum adanya metode penyimpanan dari obat, SIM RS yang belum bisa mengadopsi bentuk resep ke bentuk elektronik, petunjuk arah yang belum ada, konter farmasi yang masih menjadi satu tempat dengan konter farmasi. Implementasi intervensi yang dilakukan sesuai dengan metode lean untuk memperbaiki proses layanan di farmasi rawat jalan yaitu memindahkan konter kasir, sehingga terpisah dengan konter farmasi; Merubah lay out farmasi rawat jalan; Membuat loket antara konter farmasi dengan ruang pengerjaan obat; Mengunci pintu ruang farmasi (hanya untuk petugas farmasi) dan dibuatkan loket untuk pengorderan obat dari IGD; Merubah alur pelayanan farmasi rawat jalan lebih efektif dan efisien; Penerapan nilai-nilai lean tidak semata-mata terfokus pada aspek efisiensi tetapi terpenting juga memberikan nilai berupa customer valule, yang pada penelitian ini ditemukan perbaikan waktu tunggu, dapat dilihat pada kegiatan NVA yang dapat dieliminasi sebesar 66\% dan kegiatan VA menunjukkan peningkatan sebesar 44\%. Dengan banyaknya kegiatan yang bersifat VA dan di eliminasinya kegiatan NVA, akan mempercepat proses pelayanan farmasi rawat jalan di RSU Bali Jimbaran. Perbaikan kepuasan pelanggan yang dapat dilihat dari turunnya keluhan pelanggan terhadap layanan farmasi rawat jalan sampai 50\%. Yang sebelumnya sebesar $80 \%$.

\section{DAFTAR PUSTAKA}

Abuhejleh, A. (2002). Using Lean management to leverage innovation in healthcare projects: case study of a public hospital in the UAE. http://innovations.bmj.com/content/bmjinnov/2/1/22.full.pdf

Aditama, T. Y. (2002). Manajemen Administrasi Rumah Sakit. In Jakarta Pusat Bahasa.

Anggarani, A. (2002). Analisis Kinerja Siklus Efektifitas dikaitkan dengan Kepuasan Pelanggan terhadap Layanan Resep Farmasi Rawat Jalan di Rumah Sakit Haji Jakarta. Universitas Indonesia.

Chase, R. B. J. F. (2018). Operations and Supply Chain Management 15th ed. 
Mc.Graw-Hill Education International Edition.

Donabedian, A. (1980). The definition of quality and approaches to its assessment. Health Administration Press.

Febrianta, N. S., Sundari, S., \& Pudjaningsih, D. (2017). Waiting Time Analysis of Pharmaceutical Services with Queue Method In PKU Muhammadiyah Hospital Bantul. Int. J. Sci. Res.

Gaspersz, V., \& Fontana, A. (2011). Lean six sigma for manufacturing and service industries: waste elimination and continuous cost reduction.

Graban, M. (2012). Lean Hospital: Improving Quality, Patient Safety And Employee Engagement. CRP Press Taylor \& Francis Group.

Hadid, W. (2014). The relationship between lean service , activity-based costing and business strategy and their impact on performance. In The relationship between lean service, activity-based costing and business strategy and their impact on performance.

Herzog, N. V., \& Tonchia, S. (2014). An instrument for measuring the degree of lean implementation in manufacturing. Strojniski Vestnik/Journal of Mechanical Engineering. https://doi.org/10.5545/sv-jme.2014.1873

Houshmand, M., \& Jamshidnezhad, B. (2006). An extended model of design process of lean production systems by means of process variables. Robotics and Computer-Integrated https://doi.org/10.1016/j.rcim.2005.01.004

Manufacturing.

Howell, G. A., \& Ballard, G. (1998). Implementing Lean Construction: Understanding and Action. 6th Annual Conference of the International Group for Lean Construction.

Jeffrey K. Liker \& Michael Hoses. (2008). Toyota Culture: The Heart and Soul of the Toyota Way. International Journal of Business Management \& Research.

Kovacevic, M., Jovicic, M., Djapan, M., \& Zivanovic-Macuzic, I. (2016). Lean thinking in healthcare: Review of implementation results. International Journal for Quality Research. https://doi.org/10.18421/IJQR10.01-12

Malik, S. Z., \& Naeem, R. (2016). Organizational Virtuousness, Perceived Organizational Support and Organizational Citizenship Behavior: A Mediation Framework. Journal of Behavioural Sciences, 26(1), 113-129.

Modi, D. B., \& Thakkar, H. (2008). International Journal of Emerging Technology and Advanced Engineering Lean Thinking: Reduction of Waste, Lead Time, Cost through Lean Manufacturing Tools and Technique. Certified Journal.

Muharam, R. S. (2019). INOVASI PELAYANAN PUBLIK DALAM MENGHADAPI ERA REVOLUSI INDUSTRI 4.0 DI KOTA BANDUNG. Decision: Jurnal Administrasi Publik. https://doi.org/10.23969/decision.v1i01.1401

Nave, D. (2002). How to compare six sigma, lean and the theory of constraints. Quality Progress.

Nordin, N., Deros, B., \& Wahab, D. A. (2010). A Survey on Lean Manufacturing Implementation in Malaysian Automotive Industry. International Journal.

Notoatmodjo. (2012). Metodologi Penelitian Kesehatan Cetakan Kedua. Rineka Cipta. 
Novantri, I. (2016). Penerapan Metode Lean pada Lama Waktu Tunggu Pelayanan Rekam Medis RSUD Dr H. M. Rabain Kabupaten Muara Enim.

Noviani, E. D. (2017). Penerapan Lean Manajemen pada Pelayanan Rawat Jalan Pasien BPJS Rumah Sakit Hermina Depok Tahun 2017. Jurnal Administrasi Rumah Sakit.

Ohno, T., \& Bodek, N. (1988). Toyota Production System: Beyond Large-Scale Production (English translation edn.). Productivity Press.

Rother, M., \& Shook, J. (2003). Learning to see: Value stream mapping to add value and eliminate muda (Version 1.3. ed.). Lean Enterprise Institute.

Suryana, D. (2018). Upaya Menurunkan Waktu Tunggu Obat Pasien Rawat Jalan dengan Analisis Lean Hospital di Instalasi Farmasi Rawat Jalan RS Atma Jaya. Jurnal ARSI.

Wibowo, A. (2014). Metodologi Penelitian Praktis Bidang Kesehatan. PT. Raja Grafindo Persada.

Womack, J. P., Jones, D. T., \& Roos, D. (1992). The machine that changed the world. Business Horizons. https://doi.org/10.1016/0007-6813(92)90074-J 